\title{
Emotional Investigation on Sports Competitions Anxiety, Task and Ego Orientation among University Men Soccer Players
}

\author{
Dr. S. Binthu Mathavan \\ \{Post -Doctoral Fellow\}, Department of Physical Education and Sports, \\ Pondicherry University, Puducherry \\ sbmathavan@live.com
}

\begin{abstract}
For this investigation conducted to identify "Emotional Investigation Among Kannur University, SRM University And Pondicherry University Men Soccer Players " To do this work full forty-five subjects that were selected are all represented in the south zone inter university in the game of football in the 2014-15 academic year, the University of Calicut in Kerala. Their ages ranged from 18-28 years old, on their academic records, the subjects were selected from the following universities such as the University of Kannur, SRM University and the University of Pondicherry, from each university 15 male football players were selected totally 45, for this study to collect data sports competitions anxiety, task and ego orientation variables were limited. For data collection, a questionnaire was given to Sport the above universities male players. The collected data were analysed by analysis of variance with SPSS version 16 for evaluation of the difference among the groups. Results; In this study, no significant differences between individual universities in the variables sports competition anxiety and ego orientation but there is an significant difference among the university soccer players Pondicherry university showing better performances than the other SRM and Kannur university men soccer players on the variable of task orientation.
\end{abstract}

Keywords: sports competition anxiety, Task orientation and ego

\section{INTRODUCTION}

In this world each and every movement of human life as well all sports and games performance based on Psychological influence/ induction but it will be either negative or positive, based on percentage of anxiety task or ego level of certain situation. This is a change from the traditional behavioural-based stress analysis in sports psychology culminated in the realization that competitive anxiety, do not necessarily have a negative connotation. anxiety mental component of anxiety caused by negative expectations about the success or negative self-esteem, while the somatic anxiety physiological anxiety or affective component that is directly associated with autonomic arousal (Burton, 1988). Performance of exercise to consider the important stake in the process of child development and behaviour appropriate behaviour (Roberts 2001). Games competition provides an important context for the development of mental and moral development of young participants that peer status, peer acceptance, and self-confidence can be established and developed, and acceptance of unlike developed (e.g., Evans \& Roberts, 1987; Fox, 1988; Kavussanu \& Roberts, 2001; Roberts \& Treasure, 1995).Sport is also expected to provide a vehicle for learning to cooperate with teammates, negotiations and offer solutions to moral conflicts, develop self-control, display courage and learn the virtues of honesty, loyalty to the team, perseverance, and teamwork(e.g., Shields \& Bredemeier, 1995; Weiss \& Bredemeier, 1990). This study has been done for evaluating level of psychological influences among selected university soccer players.

\section{OBJECTIVE}

Objective for this investigation is to evaluate "Emotional Investigation among Kannur University, SRM University And Pondicherry University Men Soccer Players on selected psychological variables such as sports competition anxiety, Task and ego orientation".

\section{Methodology}

In this exploration randomly 15 men soccer players were chosen from each selected (Kannur University SRM University and Pondicherry University) totally 45 players. After that questionnaire were given to them for filling that, after filling researcher were collected that questionnaire and 
evaluated for getting score through that collected data Anova were used for statistical calculation for evaluating difference among (Kannur University SRM University and Pondicherry University) men soccer players psychological performances, the level of significance were fixed at 0.05 . and this investigation following variables were restricted such as Ego orientation, Task orientation and Sports competition anxiety.

Table1. Kannur, Srm and Pondicherry Universities Mean, Standard Deviation and 'F' Ratio Values on the Variables of Ego Orientation

\begin{tabular}{|c|c|c|c|c|c|c|c|c|c|}
\hline Name & $\begin{array}{c}\text { No of } \\
\text { subject }\end{array}$ & Mean & SD & S.E & \multicolumn{2}{|c|}{ Sum of squares } & df & $\begin{array}{c}\text { Mean } \\
\text { Square }\end{array}$ & $\mathbf{F}$ \\
\hline $\begin{array}{c}\text { Kannur } \\
\text { University }\end{array}$ & 15 & 2.580 & 0.740 & 0.191 & \multirow[t]{2}{*}{ B } & \multirow[t]{2}{*}{0.387} & \multirow[t]{2}{*}{2} & \multirow[t]{2}{*}{0.194} & \multirow{3}{*}{0.378} \\
\hline $\begin{array}{c}\text { SRM } \\
\text { University }\end{array}$ & 15 & 2.480 & 0.451 & 0.116 & & & & & \\
\hline $\begin{array}{c}\text { Pondicherry } \\
\text { University }\end{array}$ & 15 & 2.707 & 0.886 & 0.229 & $\mathbf{W}$ & 21.497 & 42 & 0.512 & \\
\hline
\end{tabular}

*The table value for significant* at 0.05 level with $2 \& 42$ degrees of freedom 'f' table value is=3.219and respectively.

Table1 showing ' $\mathrm{f}$ ' ratio results on the variable of ego orientation among Kannur University, SRM University and Pondicherry University men soccer players in that way the mean values are 2.580, 2.480 and 2.707 based on this values there is a slight difference among groups moreover the calculated ' $\mathrm{f}$ ' ratio value 0.378 is lesser than table 3.219. Hence there is no significant difference among Kannur University, SRM University and Pondicherry University men soccer players on the variable of ego orientation with the significant level of 0.05 .

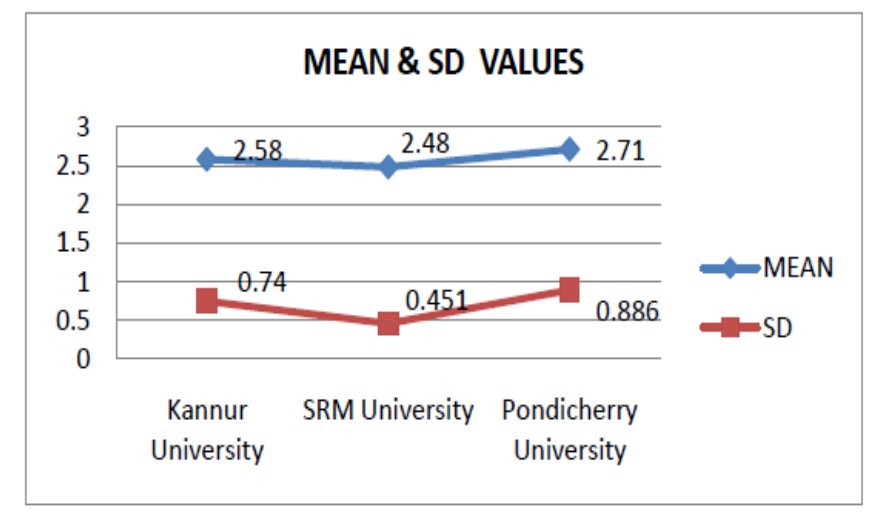

Figure1. Diagram Showing the Results of Mean and Standard Deviation for Kannur, Srm and Pondicherry Universities Men Soccer Players Performance on the Variables of Ego Orientation

Table2. Kannur, Srm and Pondicherry Universities Mean, Standard Deviation and 'F' Ratio Values on the Variables of Task Orientation

\begin{tabular}{|c|c|c|c|c|c|c|c|c|c|}
\hline Name & No of & Mean & SD & S.E & \multicolumn{2}{|c|}{ Sum of squares } & df & Mean Square & $\mathbf{F}$ \\
\hline $\begin{array}{l}\text { Kannur } \\
\text { University }\end{array}$ & 15 & 2.807 & 0.951 & 0.246 & \multirow[t]{2}{*}{ B } & \multirow[t]{2}{*}{14.563} & \multirow[t]{2}{*}{2} & \multirow[t]{2}{*}{7.282} & \multirow{4}{*}{$16.643 *$} \\
\hline $\begin{array}{l}\text { SRM } \\
\text { University }\end{array}$ & 15 & 2.627 & 0.467 & 0.121 & & & & & \\
\hline & & & & & \multirow[t]{2}{*}{$\mathbf{W}$} & \multirow[t]{2}{*}{18.376} & \multirow[t]{2}{*}{42} & \multirow[t]{2}{*}{0.438} & \\
\hline $\begin{array}{l}\text { Pondicherry } \\
\text { University }\end{array}$ & 15 & 3.913 & 0.436 & 0.112 & & & & & \\
\hline
\end{tabular}

*The table value for significant* at 0.05 level with $2 \& 42$ degrees of freedom ' $f$ ' table value is $=3.219$ and respectively. 
Table2 showing ' $\mathrm{f}$ ' ratio results on the variable of task orientation among Kannur University, SRM University and Pondicherry University men soccer players in that way the mean values are 2.807, 2.627 and 3.913 based on this values there is a slight difference among groups moreover the calculated ' $\mathrm{f}$ ' ratio value 16.643 is higher than table 3.219. Hence there is a significant difference among Kannur University, SRM University and Pondicherry University men soccer players on the variable of task orientation with the significant level of 0.05 .

Table2a. Scheffe's Post Hoc Test on Task Orientation among Kannur University, Srm University and Pondicherry University Men Soccer Players

\begin{tabular}{|c|c|c|c|c|}
\hline $\begin{array}{l}\text { Kannur } \\
\text { University }\end{array}$ & \begin{tabular}{|l|} 
SRM \\
University
\end{tabular} & $\begin{array}{l}\text { Pondicherry } \\
\text { University }\end{array}$ & \begin{tabular}{|l|} 
Mean \\
differences
\end{tabular} & CI \\
\hline 2.807 & 2.627 & & 0.18 & \multirow{3}{*}{0.622} \\
\hline & 2.627 & \begin{tabular}{|l|}
3.913 \\
\end{tabular} & $1.286^{*}$ & \\
\hline 2.807 & & \begin{tabular}{|l|}
3.913 \\
\end{tabular} & $1.106^{*}$ & \\
\hline
\end{tabular}

The Table2a showing that the Scheffe's post-hoc method of testing the significance of finding mean differences among the Kannur University, SRM University and Pondicherry University men soccer players on the variable of task orientation. For the task orientation mean values in order to magnitude the mean difference between Kannur University and SRM University is 0.18, SRM University and Pondicherry university is 1.286 , Kannur University and Pondicherry university is 1.106 and CI value is 0.622 hence this results shows there is no significant difference between Kannur university and SRM university there is significant difference between Pondicherry and Kannur university as well Pondicherry and SRM university men soccer players on the variable of task orientation.

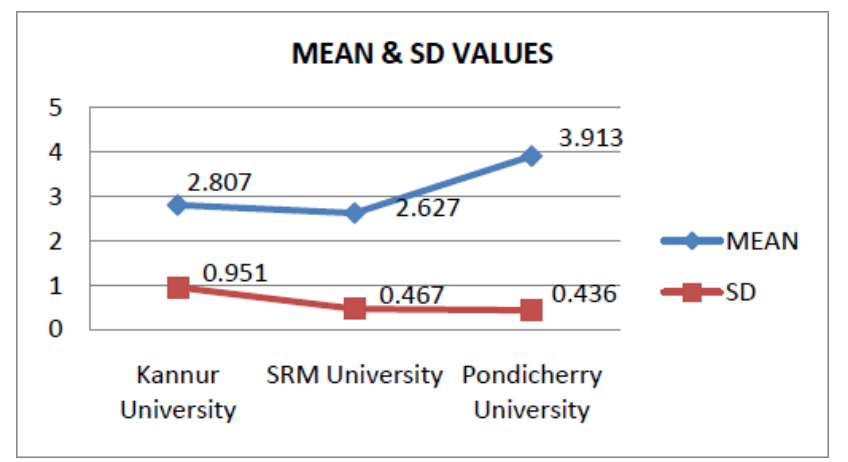

Figure2. Diagram Showing the Resultsof Mean and Standard Deviation for Kannur, Srm and Pondicherry Universities Men Soccer Players Performance on the Variables of Task Orientation

Table3. Kannur, Srm and Pondicherry Universities Mean, Standard Deviation and 'F' Ratio Values on the Variables of Sports Competition Anxiety

\begin{tabular}{|c|c|c|c|c|c|c|c|c|c|}
\hline Name & No of & Mean & SD & S.E & \multicolumn{2}{|c|}{ Sum of squares } & df & Mean Square & $\mathbf{F}$ \\
\hline \multirow{3}{*}{\begin{tabular}{|l} 
Kannur \\
University \\
SRM \\
University
\end{tabular}} & 15 & 18.467 & 3.777 & 0.568 & \multirow[t]{2}{*}{ B } & \multirow[t]{2}{*}{16.844} & \multirow[t]{2}{*}{2} & \multirow[t]{2}{*}{8.422} & \multirow{4}{*}{0.987} \\
\hline & 15 & 19.933 & 2.549 & 0.975 & & & & & \\
\hline & & & & & \multirow[t]{2}{*}{$\mathbf{W}$} & \multirow[t]{2}{*}{358.400} & \multirow[t]{2}{*}{42} & \multirow[t]{2}{*}{8.533} & \\
\hline $\begin{array}{l}\text { Pondicherry } \\
\text { University }\end{array}$ & 15 & 19.467 & 2.199 & 0.658 & & & & & \\
\hline
\end{tabular}

*The table value for significant* at 0.05 level with $2 \& 42$ degrees of freedom 'f' table value is $=3.219$ and respectively.

Table3 showing ' $\mathrm{f}$ ' ratio results on the variable of sports competition anxiety among Kannur University, SRM University and Pondicherry University men soccer players in that way the mean values are 18.467, 19.933 and 19.467 based on this values there is a slight difference among groups moreover the calculated ' $\mathrm{f}$ ' ratio value 0.987 is lesser than table 3.219. Hence there is no significant 
difference among Kannur university, SRM university and Pondicherry university men soccer players on the variable of sports competition anxiety with the significant level of 0.05 .

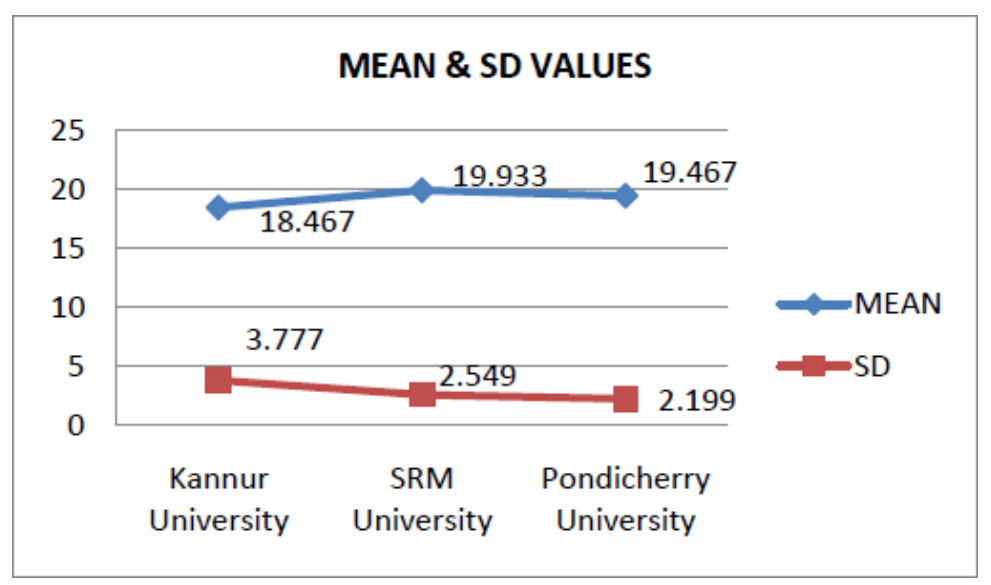

Figure3. Diagram Showing the Results of Mean and Standard Deviation for Kannur, Srm and Pondicherry Universities Men Soccer Players Performance on the Variables of Sports Competition Anxiety

\section{Conclusion}

For this investigation the selected Kannur university, SRM university and Pondicherry university men soccer players were tested with some selected psychological variables such as Ego orientation, Task orientation and sports competition anxiety among these variables there is no significant difference in Ego orientation and sports competition anxiety so it's clearly showing that above said university men soccer players are having same level of sports competition anxiety as well Ego orientation. apart from this there is a significant difference among three university men soccer players on the variable of Task orientation based on task orientation results Pondicherry university men soccer players showing better performance when compare to other Kannur university, SRM university soccer players and the Kannur university, SRM university players were showing similar level performance on the variable of task orientation so they have to develop the task orientation performance for the future competition.

\section{REFERENCES}

Ivarsson, A., \& Johnson, U. (2010). Psychological factors as predictors of injuries among senior soccer players. A prospective study. Journal of Sports Science and Medicine, 9(December 2009), 347-352.

Gonçalves, C. E., et.1., (2010). The effect of achievement goals on moral attitudes in young athletes. Journal of Sports Science and Medicine, 9(March), 605-611.

Moreno-Murcia, J. A. et.al., (2011). The relationship between goal orientations, motivational climate and selfreported discipline in physical education. Journal of Sports Science and Medicine, 10(May 2010), 119-129.

Edvardsson, A., Ivarsson, A., \& Johnson, U. (2012). Is a cognitive-behavioural biofeedback intervention useful to reduce injury risk in junior football players? Journal of Sports Science and Medicine, 11(September 2011), 331-338.

Granero-Gallegos, A.,et.al., (2012). Analysis of motivational profiles of satisfaction and importance of physical education in high school adolescents. Journal of Sports Science and Medicine, 11(July), 614-623.

Han et al., (2006). Influence of temperament and anxiety on athletic performance. Journal of Sports Science and Medicine, 5, 381-389.

Neil, R., Mellalieu, S. D., \& Hanton, S. (2006). Psychological skills usage and the competitive anxiety response as a function of skill level in rugby union. Journal of Sports Science and Medicine, 5, 415-423.

Murcia, J. A. M., Gimeno, E. C., \& Coll, D. G. C. (2007). Young athletes' motivational profiles. Journal of Sports Science and Medicine, 6(May 2006), 172-179.

Alix-Sy, D., Le Scanff, C., \& Filaire, E. (2008). Psychophysiological responses in the pre-competition period in elite soccer players. Journal of Sports Science and Medicine, 7(December), 446-454. 
Murphy, S. M., \& Woolfolk, R. L. (1987). The effects of cognitive interventions on competitive anxiety and performance on a fine motor skill accuracy task.International Journal of Sport Psychology.

Khan, Z., Haider, Z., Ahmad, N., \& Khan, S. (2011). Sports achievement motivation and sports competition anxiety: a relationship study. Journal of Education and Practice, 2(4), 1-5.

Peili, Z. (1993). Revision of The Chinese Norm of The Sports Competition Anxiety Test [J]. Psychological Science, 2, 006.

Cecchini, J., González, C., Carmona, Á., Arruza, J., Escartí, A., \& Balagué, G. (2001). The influence of the physical education teacher on intrinsic motivation, self-confidence, anxiety, and pre-and post-competition mood states. European Journal of Sport Science, 1(4), 1-11.

Skaalvik, E. M. (1997). Self-enhancing and self-defeating ego orientation: Relations with task and avoidance orientation, achievement, self-perceptions, and anxiety. Journal of educational psychology, 89(1), 71.

Duda, J. L. (1989). Relationship between task and ego orientation and the perceived purpose of sport among high school athletes. Journal of sport and exercise psychology, 11(3), 318-335.

White, S. A., \& Duda, J. L. (1994). The relationship of gender, level of sport involvement, and participation motivation to task and ego orientation.International Journal of Sport Psychology, 25(1), 4-18.

Duda, J. L., Olson, L. K., \& Templin, T. J. (1991). The relationship of task and ego orientation to sportsmanship attitudes and the perceived legitimacy of injurious acts. Research quarterly for exercise and sport, 62(1), 79-87.

Duda, J. L., Chi, L., Newton, M. L., \& Walling, M. D. (1995). Task and ego orientation and intrinsic motivation in sport. International journal of sport psychology.

Alper, T. G. (1946). Task-orientation vs. ego-orientation in learning and retention. The American journal of psychology, 236-248.

Graham, S., \& Golan, S. (1991). Motivational influences on cognition: Task involvement, ego involvement, and depth of information processing. Journal of Educational Psychology, 83(2), 187.

Treasure, D. C., \& Roberts, G. C. (1994). Cognitive and affective concomitants of task and ego goal orientations during the middle school years. Journal of Sport and Exercise Psychology, 16(1), $15-28$.

Thill, E. E., \& Brunel, P. (1995). Ego-involvement and task-involvement: Related conceptions of ability, effort, and learning strategies among soccer players. International Journal of Sport Psychology.

Newton, M., \& Duda, J. L. (1993). The relationship of task and ego orientation to performance: Cognitive content, affect, and attributions in bowling. Journal of Sport Behaviour, 16, 209-209.

Maynard, I. W., Smith, M. J., \& Warwick-Evans, L. (1995). The effects of a cognitive intervention strategy on competitive state anxiety and performance in semiprofessional soccer players. Journal of Sport and Exercise Psychology,17, 428-446. 